\title{
Mother Tongue and Learning Environment as Students' Predictors of Academic Achievement in Reading Comprehension
}

\author{
Busurat Oluwakemi Adekola ${ }^{1}$, Oluseun Fatai Lawal ${ }^{2}$ \& Olanrewaju A. Ibrahim ${ }^{3}$ \\ ${ }^{1}$ Department of Arts and Social Sciences Education, Olabisi Onabanjo University, Ago-Iwoye, Ogun State, \\ Nigeria \\ ${ }^{2}$ Institute of Education, Olabisi Onabanjo University, Ago-Iwoye, Ogun State, Nigeria \\ ${ }^{3}$ A Doctoral Student, Department of Educational Foundations and Counselling, Olabisi Onabanjo University, \\ Ago-Iwoye, Ogun State, Nigeria \\ Correspondence: Busurat Oluwakemi Adekola, Department of Arts and Social Sciences Education, Olabisi \\ Onabanjo University, Ago-Iwoye, Ogun State, Nigeria. E-mail: kemiadekola@gmail.com, \\ lawal.oluseun@yahoo.com, lanredudu4real@yahoo.com
}

Received: April 17, 2018; Accepted: May 5, 2018; Published: May 18, 2018

\begin{abstract}
The study examined mother tongue and learning environment as students' predictors of academic achievement in reading comprehension. This study adopted an ex-post facto design. The population consists of all senior secondary school students in Ijebu-North and Ijebu-Ode Local Government Area of Ogun State. A multi-stage random sampling technique was employed in selecting the sample. Four (4) senior secondary schools were randomly selected from each of the Local Government Area, making a total number of eight (8) senior secondary schools. Stratified random sampling technique was adopted in selecting 50 students from each of the selected senior secondary schools, 25 students each represent the gender totaling 400 students selected for this study. The instruments used for this study were two instruments, a questionnaire and an achievement test on reading comprehension. Kurder-Richardson 21 formula was used to obtain the inter-item reliability coefficient of 0.72 and items on achievement test on reading comprehension was extracted from a past questions of Ogun state unified examinations on English Language. The data analysis involved multiple regressions Analysis. The results were tested at 0.05 level of significance. Based on the findings, it was deduced that there is no significant composite influence of mother tongue and learning environment on students' achievement in English Language. There is no significant relative influence of mother tongue on students' achievement in reading comprehension. Part of the recommendations made was that teachers should be encouraged in using mother tongues in teaching. Teachers should cultivate a positive perception towards the use of English in school.
\end{abstract}

Keywords: academic achievement, mother tongue, learning environment

\section{Introduction}

The poor level of achievement in many subject areas especially in English language may be due to poor foundation in mother tongue among secondary school students which invariably may be connected with the conflict between mother tongue and English Language. The educational system in Nigeria should be seen to be promoting bi/multilingualism in English and Nigerian languages. Students should be able to converse meaningfully in English language and mother tongue. According to the National Policy on Education, the language of immediate environment (mother tongue) is expected to be the medium of expression from the pre-primary to primary four, this is in line with Seweje (2006) submission that 'mother tongue' is the first language that child acquires and with which he first makes contact with himself, with others and with his environment. Oluwole, (2008) while referring to Awoniyi (1978) also averred that mother tongue is defined as the language which a group of people considered to inhabitants of an area acquired in the early years and which eventually becomes their natural instrument of thoughts and communication. Mother tongue is not regarded as a garment the child puts off when he wears his school uniform but rather as a part of the staff of which his mind is built. It is therefore the language through which the child thinks, dream, cherished, loves, scolds and learns. As they grow, they sooner or later realize that the language of instruction in schools is basically in English. English Language in Nigeria serves as a medium of expression from upper part of the primary to tertiary institution (Adekola, 2006) For this reason, learners struggle in between the two languages mentally, socially, economically and educationally. 
Learning environment is a place where children learn and interact with learning facilities in order to be socialized and face the challenges in the society. Lawrence (2012) submits that learning environment include classroom spaces planning, administrative places planning, circulation spaces planning, spaces for conveniences planning, general infrastructure planning, the teachers as well as the students themselves are essential in teaching-learning process. The extent to which students' learning could be enhanced depends on their location within the school compound, the structure of their classroom, availability of instructional facilities and accessories. It is believed that a school with adequate learning environment contributes to stir up expected outcomes of learning that will facilitate good academic performance, by encouraging effective teaching and learning. Hence, learning environment takes into account several variables that have direct and indirect effect on students. Okeke (2001) consider learning environment as the second teacher since space has the power to organize and promote pleasant relationships between people of different ages, to provide changes, to promote choices and activities and for its potential for sparking different types of social and affective learning. Hence, the learning environment remains an important area that should be studied and well managed to enhance students' academic performance. The fact that learning environment can impact on students academic achievement has been established by studies (Glassman 1994, Persaud \& Turner 2008).

In Nigeria, there is need for a well planned and organized learning environmental enrichment because it fosters good interpersonal relationship. Moreover, Ajayi and Ashaolu (2005) opined that environmental enrichment regarding physical facilities is a major factor in students' academic achievement. Supporting this Ayodele (2005) and Ajayi (2007), have shown that learning environment, school resources aid students academic achievement.

This study examines mother tongue and learning environment as students' predictors of academic achievement in reading comprehension.

\section{Hypotheses}

The following hypotheses are formulated to guide this study;

1. There is no significant composite influence of mother tongue and learning environment on students' achievement in reading comprehension..

2. There is no significant relative influence of mother tongue on students' achievement in reading comprehension.

3. There is no significant relative influence of learning environment on students' achievement in reading comprehension.

\section{Materials and Methods}

The study employed the ex-post-facto research design. The population consists of all senior secondary school II (SSS2) students in Ijebu-North and Ijebu-Ode Local Government Area of Ogun State. A multi-stage random sampling technique was employed in selecting the sample. Where four (4) senior secondary schools were randomly selected from each of the Local Government Area, making a total number of eight (8) senior secondary schools selected for the study. Stratified random sampling technique was adopted in selecting 50 students from each of the selected eight senior secondary schools, where 25 students represent male and 25 students represent female in each of the selected schools. Making a total number of 400 students selected for this study.

The instruments used for this study are two instruments, a questionnaire and an achievement test on English Comprehension. The questionnaire has two sections; Section A of the instrument focuses on demographic information of the Students while Section B of the instrument contains items eliciting information from the students on Mother tongue and learning environment. The questionnaire is in a likert format which allows for either strongly agree (SA), Agree (A), strongly disagree (SD), or Disagree (D) responses from respondents. The questionnaire contains 30 items, where 15 questions elicit information on mother tongue and 15 questions are for information on learning environment. validity and reliability of the questionnaire was determined by trial testing the instrument on the similar set of the sample in some other schools that were not part of sample population and the Kurder-Richardson 21 formula was used to obtain the inter-item reliability coefficient of 0.72 and items on achievement test on English Language was extracted from a past questions of Ogun state unified examinations on English Language. This was used because it is a standardized questions set and vetted by qualified teaching personnel in Ogun State.

\section{Results and Discussion}

Hypothesis One: There is no significant composite influence of mother tongue and learning environment on academic achievement in reading comprehension. 
Table 1. Mother tongue and Learning environment as predictors of academic achievement in reading comprehension

\begin{tabular}{|c|c|c|c|c|c|c|}
\hline \multicolumn{7}{|c|}{ ANOVA $^{\mathrm{a}}$} \\
\hline Model & & Sum of Squares & Df & Mean Square & $\mathrm{F}$ & Sig. \\
\hline & Regression & 9666.646 & 2 & 4833.323 & 234.024 & $.000^{\mathrm{b}}$ \\
\hline \multirow[t]{3}{*}{1} & Residual & 2003.354 & 97 & 20.653 & & \\
\hline & Total & 11670.000 & 99 & & & \\
\hline & $\begin{array}{l}\mathrm{R}=.910 \\
\mathrm{R}^{2}=0.828 \\
\text { Adjusted } \mathrm{R}^{2}\end{array}$ & & & & & \\
\hline
\end{tabular}

a. Dependent Variable: Students academic achievement in reading Comprehension

b. Predictors: (Constant), learning environment, mothers tongue

In table 1 above, both mother tongue and learning environment as the independent variables accounts for $82.8 \%$ of the total variation in students academic achievement in reading comprehension $\left(\mathrm{R}^{2}=0.828, \mathrm{~F}=234.024, \mathrm{P}\right.$ $<0.05)$.This is significant, thus, in order to enhance better students academic achievement, both mother tongue and learning environment are important factors that need to be considered Therefore, the formulated null hypothesis one is reject and conclude statistically that there is a significant composite influence of mother tongue and learning environment on students achievement in reading comprehension. Supporting this finding were the findings of Ayodele (2005) and Ajayi (2007) who discovered that learning environment, school resources aid students academic achievement in mother tongue learning.

Hypothesis Two: There is no significant relative influence of mother tongue on academic achievement in reading comprehension

Table 2. Mothers tongue as a predictor of students' academic achievement in reading comprehension

\begin{tabular}{lllll}
\hline Parameter & Coefficient & Standard Error & T-cal & Probability \\
\hline Constant & -58.752 & 10.009 & -5.870 & .000 \\
Mother tongue & 2.787 & .255 & 10.915 & .000 \\
$\mathrm{R}^{2}$ & 0.549 & & & \\
Adjusted R & 0.544 & & & \\
F-Statistic & 119.129 & & & \\
\hline
\end{tabular}

In table 2 above, mother tongue as the only independent variable accounts for $54.9 \%$ of the total variance in students academic achievement $\left(\mathrm{R}^{2}=0.549, \mathrm{~F}=119.129, \mathrm{P}<0.05\right)$. This is significant, thus, in order to enhance students academic achievement in reading comprehension, mother tongue is an important factor that need to be considered Therefore, the null hypothesis one formulated is rejected in lieu of the alternate hypothesis which is statistically concluded that there is significant relative influence of mother tongue on students academic achievement in reading comprehension. This corroborated the assertion of Seweje (2006) who confirmed that mother tongue' is the first language that child acquires and with which he first makes contact with himself, with others and with his environment.

Hypothesis Three: There is no significant relative influence of learning environment on students' achievement in English reading comprehension

Table 3. Learning environment as a predictor of students academic achievement in reading comprehension

\begin{tabular}{lllll}
\hline Parameter & Coefficient & Standard Error & T-cal & Probability \\
\hline Constant & -43.259 & 7.033 & -6.151 & .000 \\
learning environment & 2.424 & .182 & 13.345 & .000 \\
$\mathrm{R}^{2}$ & 0.645 & & & \\
Adjusted R & 0.641 & & & \\
F-Statistic & 178.089 & & & \\
\hline
\end{tabular}


In table 3 above, learning environment as the only independent variable accounts for $64.5 \%$ of the total variation in students academic achievement in reading comprehension $\left(\mathrm{R}^{2}=0.645, \mathrm{~F}=178.089, \mathrm{P}<0.05\right)$. This is significant, thus, in order to enhance students academic achievement in reading comprehension, learning environment is an important factor that need to be considered Therefore, the null hypothesis formulated is rejected and concluded statistically that there is a significant relative influence of learning environment on students academic achievement in reading comprehension. This result is in line with the findings of Okeke (2001) who considered learning environment as a major factor determining students' academic achievement in reading comprehension

\section{Conclusion}

Conclusively, it can be deduced that both the mother tongue and learning environment individually and collectively influences students' academic achievement in reading comprehension. Thus, the role of professional ethics in promoting academic performance should be well practiced in schools by teachers and principals. Not only that in order to curb the use of mother tongue, proper measures need to be put in place. Language policies can reduce the use of mother tongue if they are implemented in the right way. An established mechanism that ensures students are rewarded and punished in equal measure can help to deter use of mother tongue and encourage use of English. It was thus concluded that teachers reward for students who use English and punishment for those who use mother tongue is important to encourage students to converse in English and deter those who intend to converse in mother tongue.

\section{Recommendations}

In view of what this research work is based on, the following recommendations are here by stated.

> Schools should be provided with functional libraries, equipped with current reading materials to help enhance both the students' academic achievement and the teachers' effectiveness in academic activities in the school.

$>$ Teachers should be encouraged in using mother tongues in teaching.

$>$ Moreover, stringent language policies that are feasible should be developed.

$>$ Teachers should cultivate a positive perception towards the use of English in school. They should be role models to the students and encourage them to converse in English.

$>$ Teachers should come up with teaching methods that are interactive and mother tongue effective to ensure that students are given an opportunity to interact with each other in English so that students can have good communication skills.

$>$ Parents and the stakeholders through P.T.A. should work to see that the learning environment conform to UNESCO standard.

$>$ Government should improve the condition of classroom by providing electric fittings besides renovations of schools.

\section{References}

Adegboyega, A. A. (2002). Trends in Public Financing of Federal Inventors in Nigeria, a Case Study of University of Ibadan in Adedeji, S. O. (ed) African Journal of Educational Planning and Policy Studies, 3(1), 95-108.

Adekola, B. O. (2006). Influence of Mother Tongue on the English Language Performance of Students in Junior School Examination. Educational Management International. A Publication of Department of Educational Management and Business Education, Olabisi Onabanjo University, Ago-Iwoye, 2(1), 43-56, ISSN: 978-3760.

Agugbuem, E. O. (2002). Taking the Distance out of the Distance Education. The Complementary Roles of Information Nigeria Education Review, 7(1), 171-179.

Akpa, G. O., Udoh, S. U., \& Fagbamiye, E. O. (2005). Deregulating the Provision and Management of Education in Nigeria. The Nigerian Association for Educational Administration and Planning (NAEAP).

Akubue, A. U., \& Ifelunni, C. S. (2006). Effect of school location on students Achievement Journal of Educational Research, (1), 109-110. University of Nigeria, Nsukka.

Aladejana, F. O., \& Odejobi, C. O. (1999). Effects of Mother Tongue on JSS students' Performance in Integrated Science. Ife J. Behav. Res., 1(1), 12.

Anglican Communion. (2000). Memorandum on the Return of Schools to their Former Owners, Lagos State Government.

Asogwa, P. U. (2008). Introduction to Natural Science-1 -Revised Edition. Printed in Nigeria and Produced by Enyi \& co (Nig), Suit 3, Pinnacle Plaza, 44 presidential Road Enugu. 
Ayodele, J. B. (2004). The Role of the Head Teachers in School Plant Management and Maintenance. In Fagbamiye, E. O., Babaloja, J. B., Fabunmi, M., \& Ayemi, A. O. Management of Primary and Secondary Education in Nigeria. Ibadan: NAEAP. 93-100.

Basque, J., \& Dare, S. W. (1998). Environment and Apparatuship Information. Journal of Distance Education, 13(1). ISSN 0830-0445

Eze, F. N. (2010) Influence of School Environment on Academic Achievement of students of public secondary School M.Ed. Thesis Department of Educational Foundation University of Nigeria, Nsukka.

Glassman, N. S. (1994). Making better decisions about school problems: How administrators use evaluation to find solutions. California: Corwin Press.

Lawrence, A. S. A. (2012). Learning Environment and Academic Achievement of Standard IX Students. Journal of Educational and Instructional Studies in the World, 2(3), 210-215.

Okeke, E. A. C. (2001). International Journal of Education Research 5.98. Institute of Education University of Nigeria Nsukka.

Oluwole, D. A. (2008) The impact of mother tongue on students' achievement in English language in Junior Secondary Certificate Examination in Western Nigeria. Journal of Social Sciences, Kamla-Raj, 17(1), 41-49. https://doi.org/10.1080/09718923.2008.11892632

Persaud, G., \& Turner, T. (2002). High definition planning for effective schools. Reflections from the FieldEducational Planning, 14(1), 65-76.

Seweje, O. (2006). Second Language Acquisition: Integrating Technology into Language Learning. Proceedings of the First National Conference on Language Teaching in a Technological World, Held Between $25^{\text {th }}$ and $28^{\text {th }}$ April. Pg 32-37.

\section{Copyrights}

Copyright for this article is retained by the author(s), with first publication rights granted to the journal.

This is an open-access article distributed under the terms and conditions of the Creative Commons Attribution license (http://creativecommons.org/licenses/by/4.0/). 